\title{
One-pot Green Synthesis of Palladium Doped Reduced Graphene Oxide Composite For Electrochemical Determination of Hydrogen Peroxide
}

\author{
Ersan Turunc ${ }^{1,2 *}$ \\ $\mathbf{1}^{*}$ Department of Nanotechnology and Advanced Materials, Institute of Science, Mersin University, 33343 Mersin, Turkey \\ ${ }^{2}$ Department of Chemistry and Chemical Processing Technologies, Technical Science Vocational School, Mersin University, Mersin, 33343 , Turkey \\ (ORCID: 0000-0001-6412-9020), ersanturunc@mersin.edu.tr
}

(First received 4 May 2021 and in final form 24 July 2021)

(DOI: $10.31590 /$ ejosat.932703)

ATIF/REFERENCE: Turunc, E. (2021). One-pot Green Synthesis of Palladium Doped Reduced Graphene Oxide Composite For Electrochemical Determination of Hydrogen Peroxide. European Journal of Science and Technology, (25), 550-555.

\begin{abstract}
In the present study, a modified electrosensor based on one-pot green synthesized palladium doped reduced graphene oxide composite $(\mathrm{Pd} @ \mathrm{rGO})$ has been developed for the electrochemical determination of hydrogen peroxide. The electrochemical features of the electrosensor was appraised by cyclic voltammetry (CV) and differential puls voltammetry (DPV) techniques. The Pd@rGO modified glassy carbon electrode exhibited a superior electroactivity as against to unmodified glassy carbon electrode (GCE). It demonstrated a superior performance toward hydrogen peroxide in the concentration range of $10 \mu \mathrm{M}$ and $1.0 \mathrm{mM}$ with a detection limit of $0.12 \mu \mathrm{M}$. The selectivity of the sensor was investigated in the presence of various biological interferents like glucose, ascorbic acid, dopamine, paracetamol and uric acid. The results showed that the electrosensor had no considerable reponse to those of intererent substances.
\end{abstract}

Keywords: Reduced graphene oxide, Electrosensor, Hydrogen peroxide, Nanocomposite, Green synthesis.

\section{Hidrojen Peroksitin Elektrokimyasal Tayini İçin Paladyum Katkılı İndirgenmiş Grafen Oksit Kompozitinin Tek Basamaklı Yeşil Sentezi}

Öz

Bu çalışmada, hidrojen peroksitin elektrokimyasal tayini için bir basamakta yeşil yöntemle sentezlenmiş paladyum katkılı indirgenmiş grafen oksit kompozitine ( $\mathrm{Pd} @ \mathrm{rGO})$ dayalı modifiye bir elektrosensör geliştirilmiştir. Elektrosensörün elektrokimyasal özellikleri, döngüsel voltametri (CV) ve diferansiyel puls voltametri (DPV) teknikleriyle değerlendirilmiştir. Pd@rGO kompozit ile modifiye edilmiş camsı karbon elektrot, modifiye edilmemiş camsı karbon elektroduna (GCE) göre üstün bir elektroaktivite sergilemiştir. Elektrosensor $0.12 \mu \mathrm{M}$ saptama limiti ile $10 \mu \mathrm{M}$ ve $1.0 \mathrm{mM}$ derişim aralığında hidrojen peroksite karşı iyi bir performans göstermiştir. Sensörün seçiciliği, glikoz, askorbik asit, dopamin, parasetamol ve ürik asit gibi girişim yapan çeşitli biyolojik moleküllerin varlığında araştırılmıştır. Sonuçlar, elektrosensörün girişim yapan maddelere karşı önemli bir cevap vermediği belirlenmiştir.

Anahtar Kelimeler: İndirgenmiş grafen oksit, Elektrosensör, Hidrojen peroksit, Nanokompozit, Yeşil sentez.

\footnotetext{
*Corresponding Author: ersanturunc@mersin.edu.tr
} 


\section{Introduction}

Graphene, due to its unrivaled atomic layered structure, unrivaled physical and electronic properties, has a very good electrical, electrochemical, optical, thermal and mechanical properties [Gan ve ark., 2019; Novoselov ve ark., 2004]. By virtue of its thermal and electrical conductivity, graphene finds application in various areas such as in strengthening nanocomposites, transparent conductive films, electronic circuits, chemical and biosensors, pharmaceutical and gene release agents, nanoelectronics and energy storage system [Geim ve ark., 2007; Geim, 2009]. Graphene oxide is layered and containing oxygenated species like epoxide, carboxyl, hydroxyl groups on their basal planes and edges, which is considered pioneer to largescale graphene synthesis [Chua ve ark., 2009]. These species not just extend the intermediate layer distance but also make the atomic-thick layers hydrophilic [Thakur ve ark., 2015; Ed ve ark., 2010]. And also these oxygen-containing functional groups can create a platform for attachment of nanoparticles, prevents nanoparticles from aggregating and enhance the stability [Hsu ve ark., 2014]. Furthermore, graphene-grafted with metallic nanoparticles have gained great importance because of their ability to exhibit synergistic effects that cause to enhance the electrocatalytic performance [Salazar ve ark., 2019]. Owing to comprising a great number of oxygen functional group on graphene oxide, it can be reduced by assorted processes like thermal annealing [Saleem ve ark., 2018], photochemical [dos Santos ve ark., 2018] and chemical [Gao ve ark, 2017]. Among these, the most applied approach is the chemical reduction method. The chemical route is based on use of hydroquinone, sodium borohydride and hydrazine as reductants [Das ve ark., 2018]. However, those chemical based reductants are extremely toxic and have noxious influence on environment and human wellness. Therefore, it is essential to evolve new eco-friendly routes for the productive reduction of graphene oxide into reduced graphene oxide [Gan ve ark., 2019]. In recent years, there have been a considerable interest to plants for nanomaterials/nanocomposites synthesis, which is eco-friendly, cost-effective and easy carry out [De Silva ve ark., 2017].

Hitherto, a large number of studies have been reported the eco-friendly one-pot synthesis of reduced graphene oxide grafted with metallic nanoparticles via plant extracts. Phyllanthus acidus, Salvadora persica L., Berberis vulgaris, Pulicaria glutinosa and Psidium guajava are to name of a few [Nayak ve ark., 2020; AlMarri ve ark., 2016; Nasrollahzadeh ve ark., 2016; Khan ve ark., 2017; Chettri ve ark., 2017]. In our recent work, we have introduced one-step route for the synthesis of reduced $\mathrm{GO} / \mathrm{Pd}$ nanocomposite using Onosma malatyana Binzet (OMB) root extract and tested on hydrogen evolution reaction [Kayan ve ark., 2021].

The genus Onosma L. is the most broad group in the Boraginaceae family and includes about 150 species that are spreaded out in Asia and Europe. It is depicted by 109 taxa (103 species) in Turkey with $50 \%$ endemism rate among native species. Onosma malatyana Binzet is an endemic species that spreads in the Eastern Anatolia provinces of Malatya and Tunceli [Binzet et al., 2016].

Hydrogen peroxide $\left(\mathrm{H}_{2} \mathrm{O}_{2}\right)$ is greatly enforced in various industry as an essential mediator in food, biology, environment, pharmaceutical and clinical, but the most application area is as a bleaching item in the textile, pulp, and paper industries [Golsheikh ve ark., 2020]. In addition, the surveys in health area, $\mathrm{H}_{2} \mathrm{O}_{2}$ suggested to be related to alzheimer's disease, myocardial infarction, atherosclerosis, Parkinson's disease and cancers [Guo ve ark., 2020]. Therefore, the determination of hydrogen peroxide is crucial for human and environmental health. Several analytical methods have been evolved for the determination of $\mathrm{H}_{2} \mathrm{O}_{2}$ such as spectrophotometry [Apyari ve ark., 2019], colorimetry, fluorescence [Liu ve ark., 2020] and electroanalytical methods [Turunc ve ark., 2021]. Among these methods, electrochemical methods have been extensively utilized for determination of hydrogen peroxide owing to their cost-effectiveness, simplicity, sensitivity and selectivity.

In this study, palladium decorated reduced graphene oxide composite modified electrosensor has been developed and used in the determination of hydrogen peroxide.

\section{Material and Method}

\subsection{Reagents}

Deionezed water was used in all experiment. Hydrogen peroxide, sulphuric acid, phosphoric acid, potassium permanganat were purchased from Merck company. Graphite powder, potasyumtetrachloro palladate(II), sodium phosphate monobasic, sodium phosphate dibasic, dopamine hydrochloride, uric acid, ascorbic acid, paracetamol and glucose were supplied from Sigma-Aldrich. O. malatyana plant was provided from Mersin University Biology Herbarium.

\subsubsection{Preparation of the extract}

For the green synthesis of nanocomposite the roots of the $\mathrm{O}$. malatyana were used. The root extract was obtained according to the procedure performed previously [Kayan ve ark., 2021]. Briefly, the roots were left to desiccate in shadow for about 10 days at room temperature. The desiccated roots were milled by crusher to get slender powder. The slender powder $(5 \mathrm{~g})$ was placed into $250 \mathrm{~mL}$ round bottom flask and boiled for $30 \mathrm{~min}$ in $100 \mathrm{~mL}$ of ultra pure water. After $30 \mathrm{~min}$ of exposure to boiling temperature, the solution was allowed to cool to room temperature, filtered and the supernatant was held in refrigerant at $+4{ }^{\circ} \mathrm{C}$ until used.

\subsubsection{Synthesis of palladium decorated reduced graphene oxide(Pd@rGO)}

Firstly, graphene oxide was synthesied by oxidation of graphite via modified Hummer's process [Tajiki ve ark., 2020]. Green synthesis of Pd@rGO nanocomposite was synthesized successfully according to the previous study and the structural characterization were given in Supplemantary files. Briefly, GO $(25 \mathrm{mg})$ was poured into water $(25 \mathrm{~mL})$ and sonicated for $30 \mathrm{~min}$. to acquire dispersed $\mathrm{GO}(1 \mathrm{mg} / \mathrm{mL}) .25 \mathrm{~mL}^{\circ}$ of $\mathrm{K}_{2} \mathrm{PdCl}_{4}(1 \mathrm{mM})$ solutions was attached to $\mathrm{GO}$ suspension $(1 \mathrm{mg} / \mathrm{mL})$ and sonicated for another $30 \mathrm{~min}$. Afterward, O. malatyana root extract were added into above concoction and refluxed at $80^{\circ} \mathrm{C}$ for $10 \mathrm{~h}$. The obtained mixture was left to cool to room temperature and separated. For comparison, rGO and pure PdNPs were synthesized by the same method as mentioned above.

\subsubsection{Characterization}

Structural morpholgy of the PdNPs, rGO and Pd@rGO nanocomposite were performed by Scanning Electron Microscopy (SEM) coupled with Energy Dispersive X-ray spectrometer (EDX) (Zeiss) and Transmission Electron Microscopy (TEM) (JEOL JEM 1011 Megaview III Camera iTEM Software) techniques. Further analysis were carried out by UV-Vis spectrometer (Shimadzu 1800 spectrophotometer), X-ray 
powder diffraction (XRD) (Rikagu diffractometer with $\mathrm{CuKa}, \lambda=$ $1.5406 \AA$ ) and Dynamic light scattering (DLS) on account of determining the formation, crystallinity, the stability of the nanomaterials, respectively. Electrochemical investigations were performed $\mathrm{CHI}$ 660E electrochemical workstation at ambient temperatures. A conventional three-electrode system was used for electrochemical studies, where the $\mathrm{Pt}$ wire and an $\mathrm{Ag} / \mathrm{AgCl}$ electrode were used as counter and reference electrodes, respectively. A glassy carbon with diameter of ca. $3 \mathrm{~mm}$ was used as working electrode.

For the electrochemical determination of hydrogen peroxide, glassy carbon electrode (GCE) was modified with biosynthisized Pd@rGO composite. Prior to modification, the glassy carbon electrode (GCE) was polished utilizing 0.30 and $0.05 \mu \mathrm{m}$ alumina powder, and sonicated in 1:1 (v:v) nitric acid, acetone and deionized water for $5 \mathrm{~min}$ to get smooth surface, respectively. The polished GCE was modified by drop-casting of Pd@rGO nanocomposite suspension $(5 \mathrm{mg} / \mathrm{mL})$. A certain amount of Pd@rGO $(8 \mu \mathrm{L})$ suspension was casted on the shiny surface, covered with beaker and left to dry at ambient temperature. Finally, $5 \mu \mathrm{L}$ of Nafion ${ }^{\circledR}(5 \%$ in alcohol) was encased by casting upon modified electrode surface. In order to the syllogism studies, rGO and PdNPs modified electrodes were prepared by subsequent the same procedure mentioned above.

\section{Results and Discussion}

\subsection{Electrochemical characterization}

Cyclic voltammetry studies were performed utilizing $1.0 \mathrm{mM}$ $\left[\mathrm{Fe}(\mathrm{CN})_{6}\right]^{4-/ 3-}$ redox couple in $0.1 \mathrm{M} \mathrm{KCl}$ solution at scan rate of $100 \mathrm{mV} / \mathrm{s}$. All of the electrodes showed a well-defined redox wave which corresponding to $\mathrm{Fe}^{2+} \leftrightarrow \mathrm{Fe}^{3+}$ process. The anodic peak current acquired for bare GCE, rGO-GCE, PdNPs-GCE and Pd@rGO-GCE were 17.5, 22.5, 26.3 and $45.2 \mu \mathrm{A}$ respectively (Fig. 3.1). From, Pd@rGO-GCE showed highest current response and lower peak-to-peak separation, it evidenced that Pd@rGO composite modified electrode facilitate the electron transfer and displayed excellent electron transfer ability as per the other modified electrode. The superior electrocatalytic activity can be assigned to the synergistic effect of PdNPs along with rGO that enhances the rate of electron transfer at the electrode electrolyte boundary.

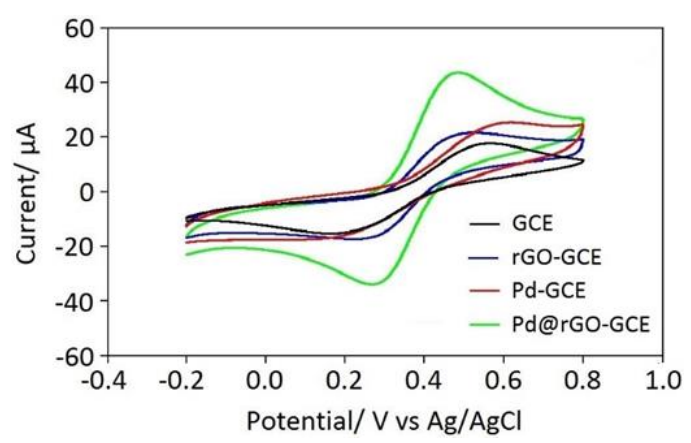

Fig. 3.1. Cyclic voltammograms of bare GCE, rGO-GCE, PdNPsGCE and Pd@rGO-GCE in $0.1 \mathrm{M} \mathrm{KCl}$ comprasing $1.0 \mathrm{mM}$ $\left[\mathrm{Fe}(\mathrm{CN})_{6}\right]^{4-/ 3-}$ redox couple.

\subsection{Electrochemical performance of Pd@rGO- GCE toward hydrogen peroxide}

For purpose of examining the electrochemical performance of the modified electrode toward $\mathrm{H}_{2} \mathrm{O}_{2}$, cyclic voltammograms were carried out to appraise the electrocatalytic efficiency of e-ISSN: 2148-2683
Pd@rGO-GCE. The electrocatalytic performance of the bare, rGO, PdNPs and Pd@rGO nanocomposite modified GCE in PBS $(\mathrm{pH}=7.0)$ medium containing $1.0 \mathrm{mM} \mathrm{H}_{2} \mathrm{O}_{2}$ in potential range between 0.0 to $-0.8 \mathrm{~V}$ vs $\mathrm{Ag} / \mathrm{AgCl}$ were given in Fig. 3.2a. As seen in Fig. 3.2a, no significant reduction response was obtained for bare GCE in presence of hydrogen peroxide. Meanwhile, rGO, PdNPs and Pd@rGO nanocomposite modified GCE exhibited well electrocatalytic reduction response for $\mathrm{H}_{2} \mathrm{O}_{2}$ at same conditions. Moreover, Pd@rGO modified electrode exhibited excellent current response which was about 2 times higher than that of other modified electrodes.

The influence of scan rate on the electrocatalytic reduction of $\mathrm{H}_{2} \mathrm{O}_{2}$ on Pd@rGO-GCE was also examined in 0.1 PBS $(\mathrm{pH}=7.0)$ media comprising $1.0 \mathrm{mM} \mathrm{H}_{2} \mathrm{O}_{2}$ at different scan rates varying from 50 to $500 \mathrm{mV} / \mathrm{s}$ (Fig. 3.2b). As can be seen in Fig. 3.2b, the current response of reduction of hydrogen peroxide rises with increment scan rate. In addition, the increased scan rate caused the reduction potential to shift to a more negative direction. Fig. 3.2c demonstrates the addiction of reduction peak current with square root of scan rate with a correlation coefficient of 0.995 . The outcome points out that the reduction of hydrogen peroxide is a characteristic diffusion-controlled electrochemical process. The relation of logarithmic peak current $(\log i)$ versus logarithmic scan rate $(\log v)$ can also give information about electrochemical process. As seen in Fig. 3.2d, the relationship between the $\log \mathrm{i}$ and $\log v$ gives a straight line with linear equation $\log i=0.429 \log$ $v+1.04$ and correlation coefficient of 0.994 . The slope value of 0.429 , which is close to 0.5 [Turunc ve ark., 2020], indicates that the diffusion process control the electrochemical reduction of hydrogen peroxide. This result confirms that the electrochemical reduction of hydrogen peroxide is controlled by the diffusion phenomenon.
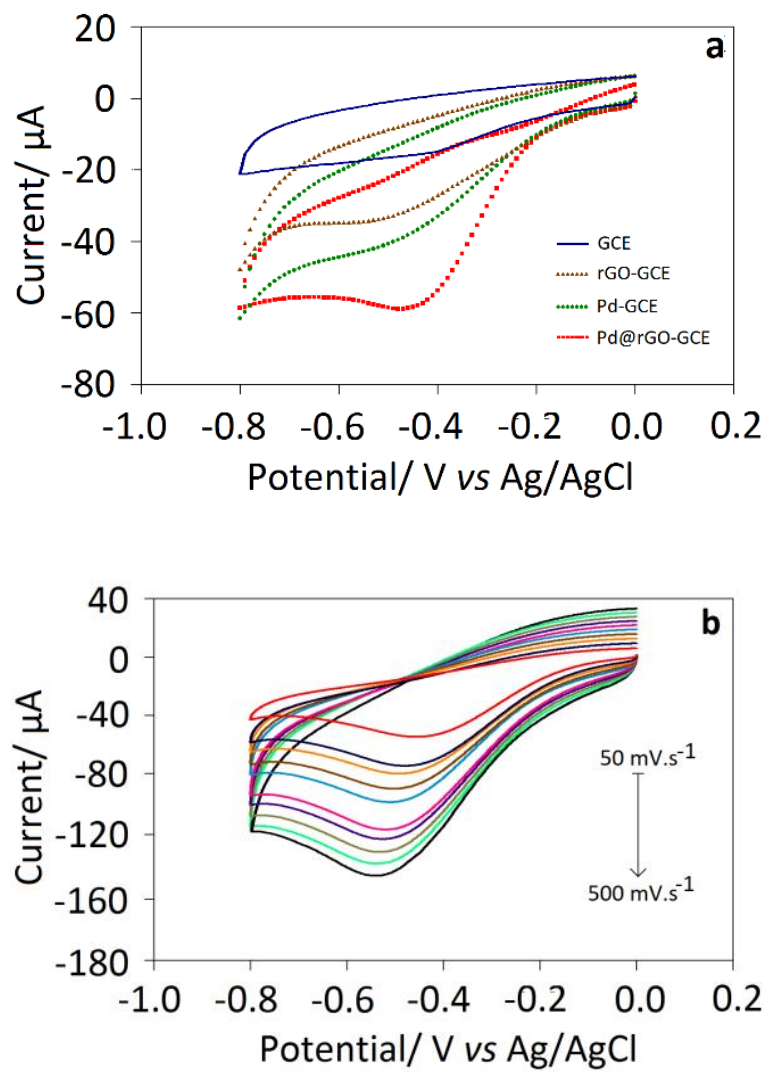

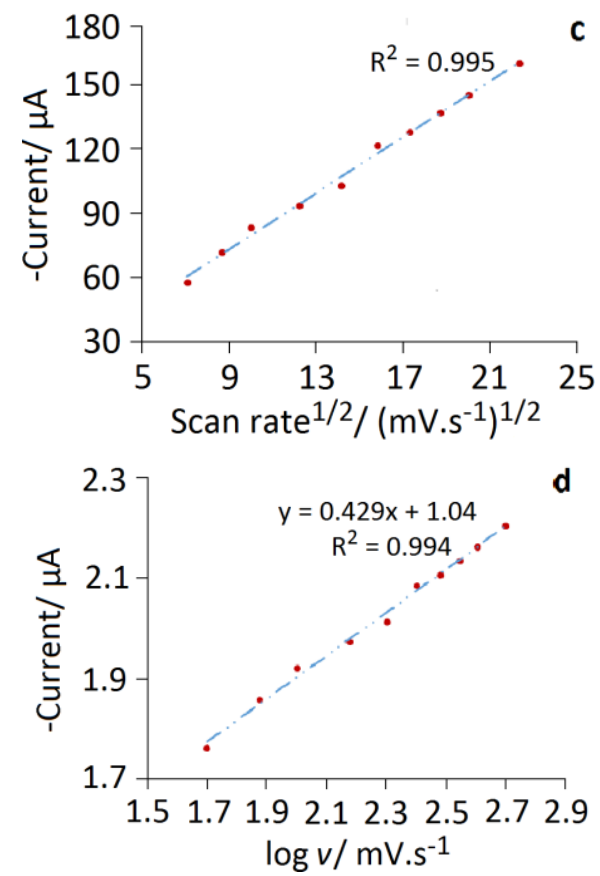

Fig. 3.2. $\mathrm{CV}$ diagrams of GCE, rGO-GCE, Pd-GCE and $\mathrm{Pd} @$ rGO-GCE in $0.1 \mathrm{M}$ PBS ( $\mathrm{pH} 7.0$ ) comprising $1.0 \mathrm{mM} \mathrm{H}_{2} \mathrm{O}_{2}$ with a scan rate of $50 \mathrm{mV} / \mathrm{s}$ (a), CV diagrams of $\mathrm{Pd} @ \mathrm{rGO}-\mathrm{GCE}$ in $0.1 \mathrm{M}$ PBS $\left(\mathrm{pH}=7.0\right.$ ) comprasing $1.0 \mathrm{mM} \mathrm{H}_{2} \mathrm{O}_{2}$ at different scan rate (b), the relation of cathodic peak current and square root of scan rate (c) and the variation of logarithmic peak current via logarithmic scan rate $(d)$.

Further investigation was carried using amperometric technique. The amperometric $i-\mathrm{t}$ studies was performed at constant potential $\left(-0.40 \mathrm{~V}_{\mathrm{Ag} / \mathrm{AgCl}}\right)$ in a continuously mixed solution of 0.1 M PBS. The amperometric response of Pd@rGOGCE to sequential addition of $\mathrm{H}_{2} \mathrm{O}_{2}$ was recorded for a period of time (Fig. 3.3). The reduction current was prominent raised with sequential addition of $\mathrm{H}_{2} \mathrm{O}_{2}$ and the current response of the modified electrode was observed within ca $3 \mathrm{~s}$, representing that Pd@rGO-GCE displays fast response for electrochemical reduction of $\mathrm{H}_{2} \mathrm{O}_{2}$.

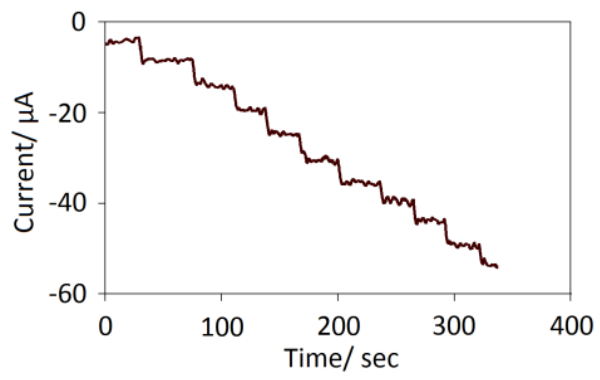

Fig. 3.3. Amperometric $i$ - t response of $\mathrm{Pd} @ \mathrm{rGO}-\mathrm{GCE}$ for the sequential addition of $\mathrm{H}_{2} \mathrm{O}_{2}$ into well-mixed $0.1 \mathrm{M}$ PBS at -0.40 $\mathrm{V}$.

\subsection{Electrochemical determination of hydrogen peroxide}

Further analysis was realized by using differential pulse voltammetry (DPV) technique to determine the performance of the Pd@rGO-GCE as a sensor (Fig. 3.4). Fig. 3.4 depicts the differential puls voltammograms and the linear plot of $\mathrm{H}_{2} \mathrm{O}_{2}$ solutions with concentrations ranging from $10 \mu \mathrm{M}$ to $1.0 \mathrm{mM}$ in 0.1 M PBS ( $\mathrm{pH}=7.0)$ utilizing Pd@rGO-GCE. It can be seen from the DPV that there is a commensurate increase in current response with raising $\mathrm{H} 2 \mathrm{O} 2$ concentration, with linear equation of $\mathrm{I}(\mu \mathrm{A})=42.87\left[\mathrm{H}_{2} \mathrm{O}_{2}\right](\mathrm{mM})+15.18\left(\mathrm{R}^{2}=0.995\right)$. The limit of detection (LOD) and the sensitivity were calculated to be $0.12 \mu \mathrm{M}$ and $42.87 \mu \mathrm{A} / \mathrm{mM}$, respectively. It can be inferred that the Pd@rGO-GCE exhibited a good electroactivity with low LOD. For the purpose of appraise the performance of the developed electrode, the $\mathrm{Pd} @ \mathrm{rGO}-\mathrm{GCE}$ sensor was checked against previously reported $\mathrm{H}_{2} \mathrm{O}_{2}$ sensors and listed in Table 1 .
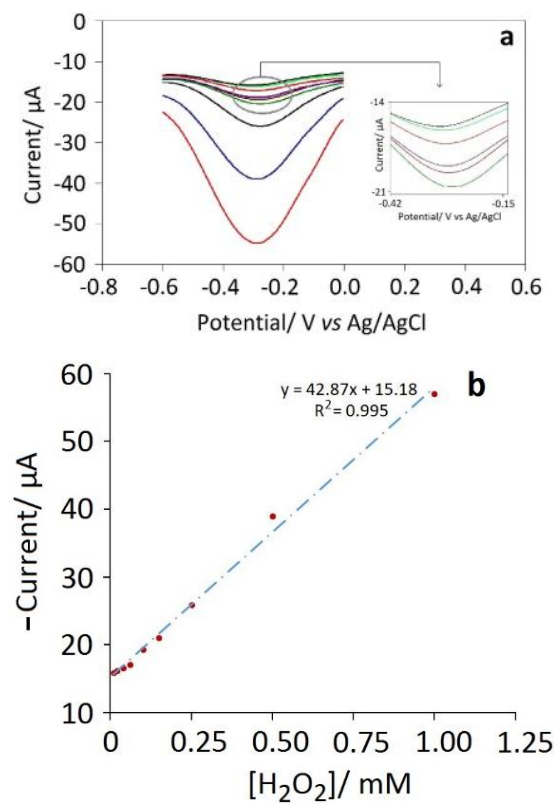

Fig. 3.4. Differantial puls voltammetric responses of $\mathrm{Pd} @ \mathrm{rGO}-$ GCE against to different concentrations of $\mathrm{H}_{2} \mathrm{O}_{2}$ in $0.1 \mathrm{M}$ PBS $(\mathrm{pH}=7.0)$. Inset diagram isthe magnification of voltammograms of the lower concentration region, and (b) the linear plot of the DPV current response versus $\mathrm{H}_{2} \mathrm{O}_{2}$ concentration.

\subsection{Interference, reproducibility and stability studies}

Alongside the LOD and sensitivity, interference property and reproducibility are also significant parameters for electrochemical sensors. Fig. 3.5a demonstrates the amperometric current response of the $\mathrm{Pd} @ \mathrm{rGO}-\mathrm{GCE}$ toward $\mathrm{H}_{2} \mathrm{O}_{2}$ in presence of interfering species such as ascorbic acid, glucose, paracetamol, dopamine and uric acid. As represented in Fig. 5a, no current response was pursued with addition of interfering species, shows that the $\mathrm{Pd} @ \mathrm{rGO}$ sensor exhibits good selectivity against $\mathrm{H}_{2} \mathrm{O}_{2}$ at $-0.40 \mathrm{~V}$.

The reproducibility of the $\mathrm{Pd} @ \mathrm{rGO}$ modified electrode was examined by four electrodes for $1.0 \mathrm{mM} \mathrm{H}_{2} \mathrm{O}_{2}$, with relative standart deviation of $2.60 \%$ (Fig. 3.5b).

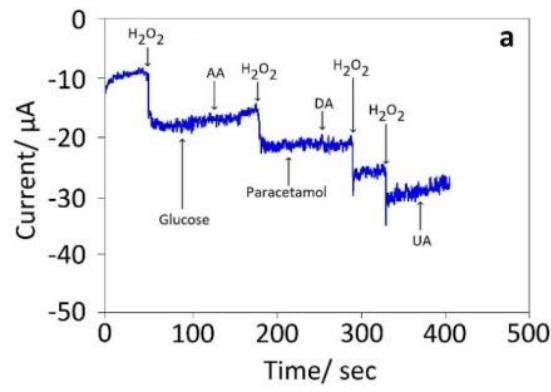




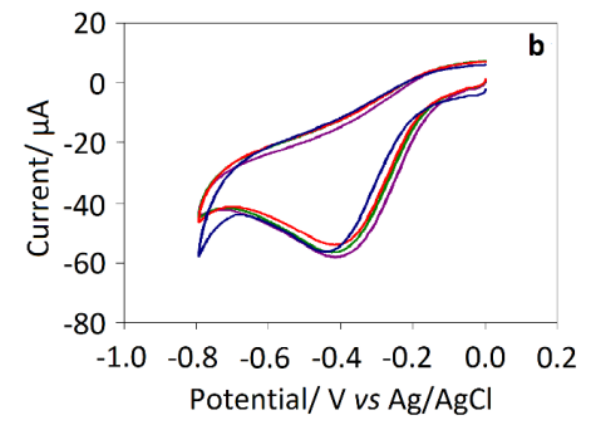

Fig. 3.5. Amperometric response of $\mathrm{Pd} @ \mathrm{rGO}-\mathrm{GCE}$ to consecutive addition of $\mathrm{H}_{2} \mathrm{O}_{2}$ and interfering species (a) and $\mathrm{CV}$ diagram of four indepent Pd@rGO-GCE in 0.1 M PBS $(\mathrm{pH}=7.0)$ comprising $1.0 \mathrm{mM} \mathrm{H}_{2} \mathrm{O}_{2}$. Scan rate is $50 \mathrm{mV} . \mathrm{s}^{-1}$.

Table 1. The electroanalytical performance of the various $\mathrm{H}_{2} \mathrm{O}_{2}$ sensors

\begin{tabular}{|c|c|c|c|c|}
\hline Electrode & Concentration range & LOD $(\mu \mathrm{M})$ & Sensitivity & Reference \\
\hline $\mathrm{CuS} / \mathrm{GR}$ & $5 \mu \mathrm{M}-1.5 \mathrm{mM}$ & 0.27 & - & [Bai ve ark., 2013] \\
\hline GO- $\mathrm{Cu}^{2+}$ composite & $5 \mu \mathrm{M}-85 \mu \mathrm{M}$ & 0.50 & $72 \mu \mathrm{A} \cdot \mathrm{mM}^{-1}$ & [Muralikrishna ve ark., 2016] \\
\hline AuNPS/ZnO/Gr & $6 \mu \mathrm{M}-1.13 \mathrm{mM}$ & 0.80 & - & [Xie ve ark., 2013] \\
\hline 3D RGO-MoS 2 QDs & $10 \mu \mathrm{M}-5.57 \mathrm{mM}$ & 1.9 & - & [Lin ve ark., 2018] \\
\hline $\mathrm{rGO} / \mathrm{FeNPs}$ & $0.1 \mu \mathrm{M}-2.15 \mathrm{mM}$ & 0.056 & $98 \mu \mathrm{A} \cdot \mathrm{mM}^{-1}$ & [Amanullan ve ark., 2017] \\
\hline $\mathrm{Au} / \mathrm{rGO}$ & $20 \mu \mathrm{M}-10 \mathrm{mM}$ & 0.10 & $1238 \mu \mathrm{A} \cdot \mathrm{mM}^{-1} \cdot \mathrm{cm}^{-2}$ & [Dhara ve ark., 2016] \\
\hline Cat- $\mathrm{Fe}_{3} \mathrm{O}_{4} / \mathrm{rGO}$ & $3.3 \mu \mathrm{M}-55.6 \mathrm{mM}$ & 0.11 & $1840 \mu \mathrm{A} \cdot \mathrm{mM}^{-1} \cdot \mathrm{cm}^{-2}$ & [Kıranşan ve ark., 2018] \\
\hline RGO-PtNPs & $0.05 \mu \mathrm{M}-0.75 \mathrm{mM}$ & 0.016 & $2550 \mu \mathrm{A} \cdot \mathrm{mM}^{-1} \cdot \mathrm{cm}^{-2}$ & [Palansimay ve ark., 2015] \\
\hline $\mathrm{RGO} @ \mathrm{CeO}_{2} / \mathrm{Ag}$ & $0.5 \mu \mathrm{M}-12 \mathrm{mM}$ & 0.21 & - & [Yao ve ark., 2016] \\
\hline $\mathrm{Ag} / \mathrm{Co}_{3} \mathrm{O}_{4} / \mathrm{RGO}$ & $0.5 \mu \mathrm{M}-7.5 \mathrm{mM}$ & 0.30 & $146.5 \mu \mathrm{A} \cdot \mathrm{mM}^{-1} . \mathrm{cm}^{-2}$ & [Wu ve ark., 2016] \\
\hline $\mathrm{Pd} @ \mathrm{rGO}$ & $10 \mu \mathrm{M}-1 \mathrm{mM}$ & 0.12 & $42.87 \mu$ A.mM $\mathrm{mM}^{-1}$ & This study \\
\hline
\end{tabular}

\section{Conclusions}

In the present study, green synthesized Pd@rGO, which was previously utilized on hydrogen evaluation reaction, based electrosensor was prepared and investigated its usability in the electrochemical determination of hydrogen peroxide. For comparison, PdNPs and rGO based electrosensor were also constructed and tested on electrorduction of $\mathrm{H}_{2} \mathrm{O}_{2}$ using $\mathrm{CV}$ in PBS media. The results showed that Pd@rGO-GCE exhibited superior electrocatalytic performance due to synergitic effect of the composite modified electrode. The DPV studies were performed in wide range of concentration between $10 \mu \mathrm{M}$ and 1 $\mathrm{mM}$ and the LOD was found to be $0.12 \mu \mathrm{M}$. Amperometric investigations showed that the interfering substances had no considerable effect on electrochemical determination of $\mathrm{H}_{2} \mathrm{O}_{2}$ at $-0.40 \mathrm{~V}$. This indicates that $\mathrm{Pd} @ \mathrm{rGO}-\mathrm{GCE}$ is highly sensitive to $\mathrm{H}_{2} \mathrm{O}_{2}$. Based on performance characteristics such as fast response, wide linear concentration range, low LOD and high sensitivity, it can be recommended that the $\mathrm{Pd} @$, rGO can be used as an $\mathrm{H}_{2} \mathrm{O}_{2}$ sensor.

\section{References}

Al-Marri, A.H., Khan, M., Shaik, M.R., Mohri, N., Adil, S.F., Kuniyil, M., Alkhathlan, H.Z., Al-Warthan, A., Tremel, W., Tahir, M.N., Khan, M., Siddiqui, M.R.H. (2016). Green synthesis of Pd@graphene nanocomposite: Catalyst for the selective oxidation of alcohols. Arabian Journal of Chemistry, 9, 835-845.

Amanulla, B., Palanisamy, S., Chen, S.M., Velusamy, V., Chiu, T.W., Chen, T.W., Ramaraj, S.K. (2017). A non-enzymatic amperometric hydrogen peroxide sensor based on iron nanoparticles decorated reduced graphene oxide nanocomposite. Journal of Colloid and Interface Science, 487, 370-377.

Apyari, V.V., Terenteva, E.A., Kolomnikova, A.R., Garshev, A.V., Dmitrienko, S.G., Zolotov, Y.A. (2019). Potentialities of differently-stabilized silver nanoparticles for spectrophotometric determination of peroxides. Talanta, 202, 51-58.

Bai, J., Jiang, X. (2013). A Facile One-Pot Synthesis of Copper Sulfide-Decorated Reduced Graphene Oxide Composites for Enhanced Detecting of $\mathrm{H} 2 \mathrm{O} 2$ in Biological Environments. Analytical Chemistry, 85(17), 8095-8101.

Binzet, R. (2016). A new species of Onosma L. (Boraginaceae) from Anatolia. Turkish Journal of Botany, 40, 194-200.

Chettri, P., Vendamani, V.S., Tripathi, A., Singh, M.K., Pathak, A.P., Tiwari, A. (2017). Green synthesis of silver nanoparticle-reduced graphene oxide using Psidium guajava and its application in SERS for the detection of methylene blue. Applied Surface Science, 406, 312-318.

Chua, C.K., Pumera, M. (2015). Monothiolation and Reduction of Graphene Oxide via One-Pot Synthesis: Hybrid Catalyst for Oxygen Reduction. ACS Nano, 9, 4193-4199.

Das, T.K., Bhawal, P., Ganguly, S., Mondal, S., Das, N. Ch. (2018). A facile green synthesis of amino acid boosted Ag decorated reduced graphene oxide nanocomposites and its catalytic activity towards 4-nitrophenol reduction. Surfaces and Interfaces, 13, 79-91.

De Silva, K.K.H., Huang, H.H., Joshi, R.K., Yoshimura M. (2017). Chemical reduction of graphene oxide using green reductants. Carbon, 119, 190-199.

Dhara, K., Ramachandran, T., Nair, B.G., Babua, T.G.S. (2016). $\mathrm{Au}$ nanoparticles decorated reduced graphene oxide for the 
fabrication of disposable nonenzymatic hydrogen peroxide sensor. Journal of Electroanalytical Chemistry, 764, 64-70.

dos Santos, P.L., Katic, V., Toledo, K.C.F., Bonacin, J.A. (2018). Photochemical one-pot synthesis of reduced graphene oxide/Prussian blue nanocomposite for simultaneous electrochemical detection of ascorbic acid, dopamine, and uric acid. Sensors and Actuators B: Chemical, 255, $2437-$ 2447.

Eda, G., Chhowalla, M. (2010). Chemically Derived Graphene Oxide: Towards Large-Area Thin-Film Electronics and Optoelectronics. Advanced Materials, 22, 2392-2415.

Gan, L., Li, B., Chen, Y., Yu, B., Chen, Z. (2019). Green synthesis of reduced graphene oxide using bagasse and its application in dye removal: A waste-to-resource supply chain. Chemosphere, 219, 148-154.

Gan, L., Li, B., Chen, Y., Yu, B., Chen, Z. (2019). Green synthesis of reduced graphene oxide using bagasse and its application in dye removal: A waste-to-resource supply chain. Chemosphere, 219, 148-154.

Gao, F., Wang, Q., Gao, N., Yang, Y., Cai, F., Yamane, M., Gao, F., Tanaka, H. (2017). Hydroxyapatite/chemically reduced graphene oxide composite: Environment-friendly synthesis and high-performance electrochemical sensing for hydrazine. Biosensors and Bioelectronics, 97, 238-245.

Geim, A.K. (2009). Graphene: Status and Prospects. Science 324, 1530-1534.

Geim, A.K., Novoselov, K.S. (2007). The rise of graphene. Nature Materials, 6, 183-191.

Golsheikh, A.M., Yeap, G.Y., Yam, F.K., Lim, H.S. (2020). Facile fabrication and enhanced properties of copper-based metal organic framework incorporated with graphene for nonenzymatic detection of hydrogen peroxide. Synthetic Metals, 260, 116272.

Guo, Z.Y., Feng, Y.F., Chen, Y.Y., Yao, Q.H., Luo, H.Z., Chen, X. (2020). A taurine-functionalized 3D graphene-based foam for electrochemical determination of hydrogen peroxide. Talanta, 208, 120356.

Hsu, K.C., Chen, D.H. (2014). Green synthesis and synergistic catalytic effect of Ag/reduced graphene oxide nanocomposite. Nanoscale Research Letters, 9, 484.

Kayan, D.B., Turunc, E. (2021). Bio-reduced GO/Pd nanocomposite as an efficient and green synthesized catalyst for hydrogen evolution reaction. International Journal of Energy Research, 1-11. https://doi.org/10.1002/er.6597.

Khan, M., Kuniyil, M., Shaik, M.R., Khan, M., Adil, S.F., AlWarthan, A., Alkhathlan, H.Z., Tremel, W., Tahir, M.N., Siddiqui, M.R.H. (2017). Plant Extract Mediated EcoFriendly Synthesis of Pd@Graphene Nanocatalyst: An Efficient and Reusable Catalyst for the Suzuki-Miyaura Coupling. Catalysts, 7, 20.

Kıranşan, K.D., Aksoy, M., Topçu, E. (2018). Flexible and freestanding catalase-Fe3O4/reduced graphene oxide paper: Enzymatic hydrogen peroxide sensor applications. Materials Research Bulletin, 106, 57-65.

Lin, D., Su, Z., Wei, G. (2018). Three-dimensional porous reduced graphene oxide decorated with MoS2 quantum dots for electrochemical determination of hydrogen peroxide. Materials Today Chemistry, 7, 76-83.

Liu, T., Zhang, S., Liu, W., Zhao, S., Lu, Z., Wang, Y., Wang, G., Zou, P., Wang, X., Zhao, Q., Rao, H. (2020). Sensors and Actuators B: Chemical, 305, 127524.

Muralikrishna, S., Cheunkar, S., Lertanantawong, B., Ramakrishnappa, T., Nagaraju, D.H., Surareungchai, W., R.
Balakrishna, G., Reddy, K.R. (2016). Journal of Electroanalytical Chemistry, 776, 59-65.

Nasrollahzadeh, M., Sajadi, S.M., Vartooni, A.R., Alizadeh, M., Bagherzadeh, M. (2016). Green synthesis of the Pd nanoparticles supported on reduced graphene oxide using barberry fruit extract and its application as a recyclable and heterogeneous catalyst for the reduction of nitroarenes. Journal of Colloid and Interface Science, 466, 360-368.

Nayak S.P., Ramamurthy, S.S., Kumar, J.K.K. (2020). Green synthesis of silver nanoparticles decorated reduced graphene oxide nanocomposite as an electrocatalytic platform for the simultaneous detection of dopamine and uric acid. Materials Chemistry and Physics, 252, 123302.

Novoselov, K.S., Geim, A.K., Morozov, S.V., Jiang, D., Zhang, Y., Dubonos, S.V., Grigorieva, I.V., Firsov, A.A. (2004). Electric Field Effect in Atomically Thin Carbon Films. Science, 306, 666-669.

Palanisamy, S., Lee, H.F., Chen, S.M., Thirumalraj, B. (2015). An Electrochemical Facile Fabrication of Platinum Nanoparticle Decorated Reduced Graphene Oxide; Application for Enhanced Electrochemical Sensing of H2O2. RSC Advances, 5, 105567-105573.

Salazar, P., Fernandez, I., Rodríguez, M.C., Creus, A.H., Mora, J.L.G. (2019). One-step green synthesis of silver nanoparticle-modified reduced graphene oxide nanocomposite for $\mathrm{H} 2 \mathrm{O} 2$ sensing applications. Journal of Electroanalytical Chemistry, 855, 113638.

Saleem, H., Haneef, M., Abbasi, H.Y. (2018). Synthesis route of reduced graphene oxide via thermal reduction of chemically exfoliated graphene oxide. Materials Chemistry and Physics, 204, 1-7.

Tajiki, A., Abdouss, M., Sadjadi, S., Mazinani, S. (2020). Voltammetric Detection of Nitrite Anions Employing Imidazole Functionalized Reduced Graphene Oxide as an Electrocatalyst. Electroanalysis, 32, 2290-2298.

Thakur, S., Karak, N. (2015). Alternative methods and naturebased reagents for the reduction of graphene oxide: A review. Carbon, 94, 224-242.

Turunc, E., Gumus, I., Arslan, H. (2020). Redox active Co(II) complex modified carbon paste electrode for the determination of dopamine. Materials Chemistry and Physics, 243, 122597.

Turunc, E., Kahraman, O., Binzet, R. (2021). Green synthesis of silver nanoparticles using pollen extract: Characterization, assessment of their electrochemical and antioxidant activities. Analytical Biochemistry, 621, 114123.

Wu, Q., Sheng, Q., Zheng, J. (2016). Nonenzymatic amperometric sensing of hydrogen peroxide using a glassy carbon electrode modified with a sandwich-structured nanocomposite consisting of silver nanoparticles, $\mathrm{Co} 3 \mathrm{O} 4$ and reduced graphene oxide. Microchimica Acta, 183, $1943-$ 1951.

Xie, L., Xu, Y., Cao, X. (2013). Hydrogen peroxide biosensor based on hemoglobin immobilized at graphene, flower-like zinc oxide, and gold nanoparticles nanocomposite modified glassy carbon electrode. Colloids and Surfaces B: Biointerfaces, 107, 245-250.

Yao, Z., Yang, X., Wu, F., Wu, W., Wu, F. (2016). Synthesis of differently sized silver nanoparticles on a screen-printed electrode sensitized with a nanocomposites consisting of reduced graphene oxide and cerium(IV) oxide for nonenzymatic sensing of hydrogen peroxide. Microchimica Acta, 183, 2799-2806. 


\title{
Supplemantary Information
}

\section{One-pot Green Synthesis of Palladium Doped Reduced Graphene Oxide Composite For Electrochemical Determination of Hydrogen Peroxide}

\author{
Ersan Turunc ${ }^{1,2 *}$ \\ $1^{1^{*}}$ Department of Nanotechnology and Advanced Materials, Institute of Science, Mersin University, 33343 Mersin, Turkey \\ ${ }^{2}$ Department of Chemistry and Chemical Processing Technologies, Technical Science Vocational School, Mersin University, Mersin, 33343 , Turkey \\ (ORCID: 0000-0001-6412-9020), ersanturunc@mersin.edu.tr
}

The structural features of rGO, PdNPs and Pd@rGO nanocomposite were realized utilizing SEM and TEM analyses. EDX analysis was performed to identify the chemical composition of the Pd@rGO nanocomposite. The SEM images elicited that $\mathrm{rGO}$ had a layered structure (Figure 1.1a). As depicted in Figure 1.1b, PdNPs were in worm-like form. SEM image of Pd@rGO nanocomposite showed that the spherical Pd nanoparticles were homogeneously distributed on the surface of rGO layers (Figure 1.1c and d). The structual property of Pd@rGO nanocomposite was also ratified by TEM analysis (Figure 1.1e and f). As can be seen in Figure 1.1e and f, spherical palladium is homogeneous dispensed on the surface of GO stratum. EDX analysis was also performed to specify the composition of the nanocomposite (Figure 1.1g). EDX spectra showed that Pd@rGO nanocomposite comprise of Pd elements confirming the presence of PdNPs on the rGO sheets.
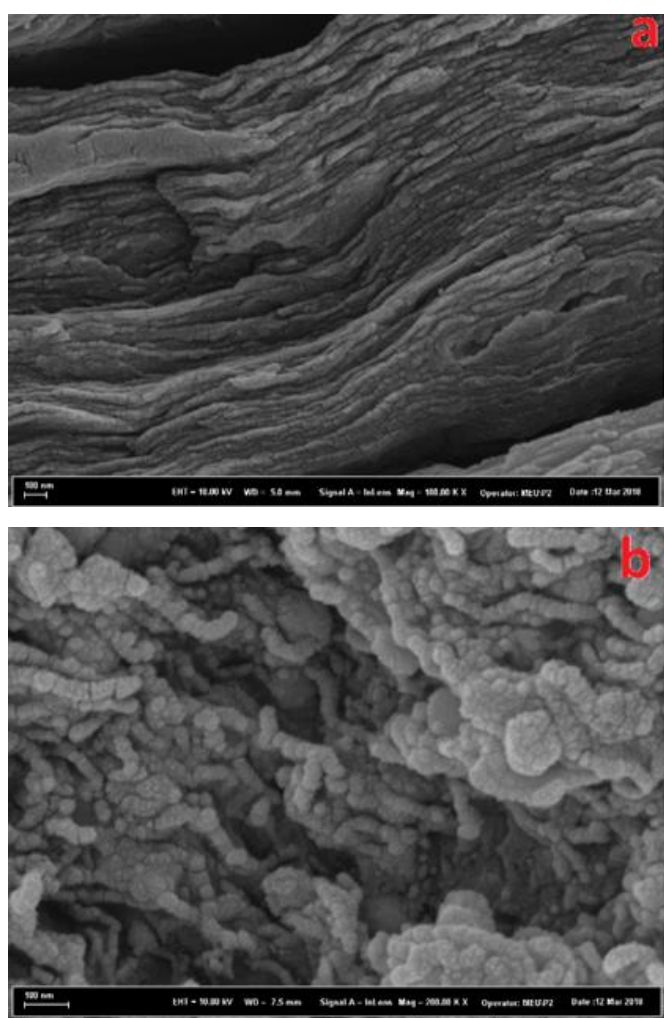
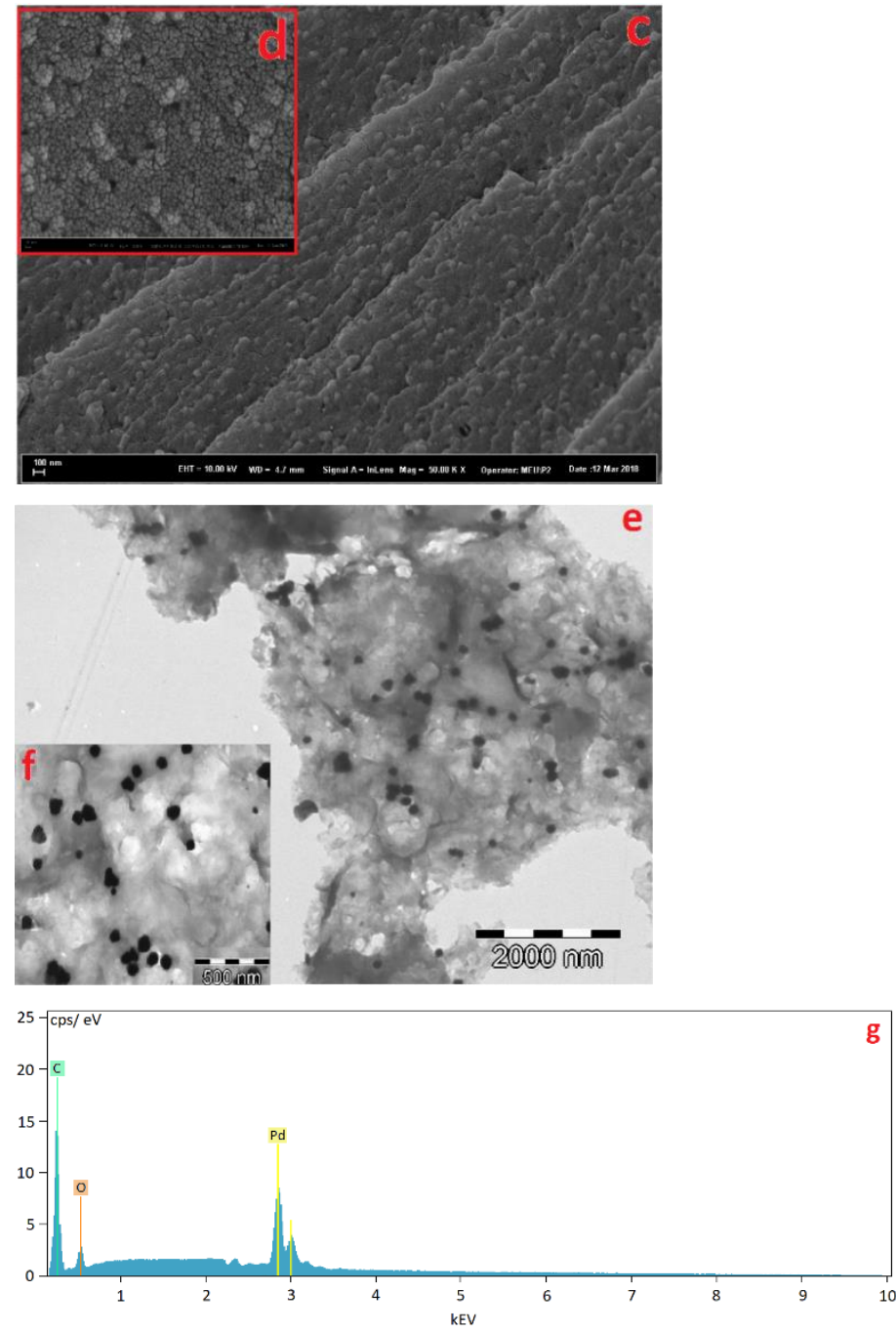

Fig. 1.1. SEM images of (a) rGO, (b) PdNPs, (c) and (d) Pd@rGO and its magnification view, (e) and (f) TEM image of Pd@rGO nanocomposite and its magnification view and (g) EDX spectra of Pd@rGO nanocomposite.

The zeta potential of rGO, Pd-rGO nanocomposite in aqueous solution is measured in a Dynamic Light Scattering (DLS) instrument to observe the amount of stability (Fig. 1.2). The rGO shows an average zeta potential value of $-16.6 \mathrm{mV}$ explaining the existence of a sufficient amount of negative charge density arising from the carboxylic groups present in the rGO. Compared to $\mathrm{rGO}$ the synthesized Pd@rGO nanocomposite exhibits a zeta potential 
of $-25.3 \mathrm{mV}$. The presence of PdNPs in GO contributed to the increase of repulsion forces and to the facilitation of the stability of the nanocomposite.

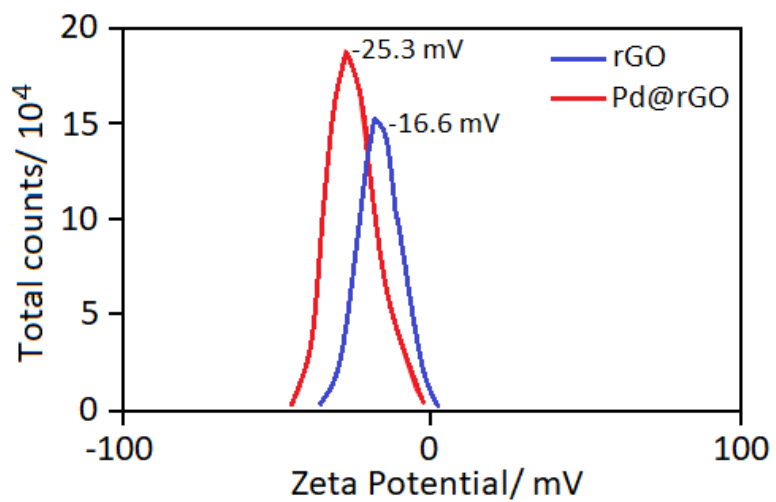

Fig. 1.2. Zeta potential of rGO and Pd@rGO aqueous dispersion.

To identify the crystalline structure and monitor the chemical alteration of the graphite during bio-reduction proces, XRD analyses were carried out.

The purity and crystallinity nature of the synthesized rGO and $\mathrm{Pd} @$ rGO nanocomposite were characterized by X-ray diffraction analysis. As seen in Fig. 1.3a, a sharp peak at $11.25^{\circ}$ correspond to (001) planes represents the successful oxidation of graphite to GO. After bio-reduction process, the diffraction peak of GO shifted to around $2 \theta$ of $24.0^{\circ}$ which correspond to (002) planes of rGO (Fig. 1.3b). In case of Pd@rGO, owing to the inclusion of PdNPs in rGO, the broad diffraction peak of rGO was faded away and three diffraction peaks were observed. The diffraction peaks settled at $39.98^{\circ}, 46.47^{\circ}$ and $67.88^{\circ}$ which can be indexed the PdNPs (ICDD: 00-005-0681) planes distrubuted on rGO as (111), (200) and (220), respectively. In the light of XRD patterns, it was concluded that Pd@rGO nanocomposite was successfully synthesized through one-step.
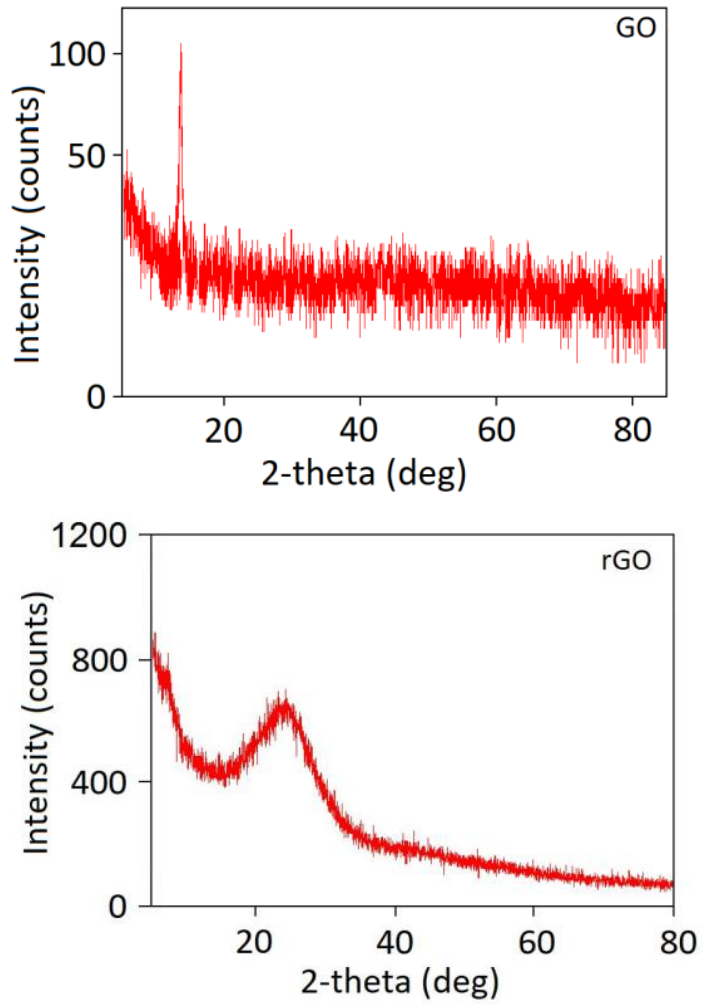

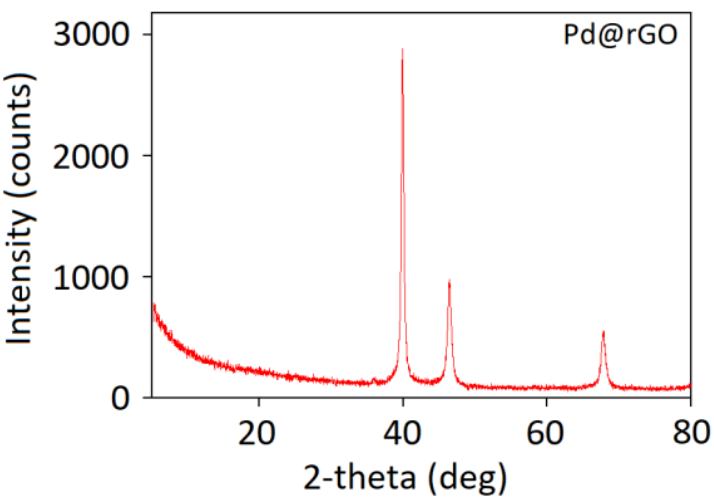

Fig. 1.3. XRD spectra of GO,rGO and Pd@rGO nanocomposite.

To approve the bio-genesis of the rGO and $\mathrm{Pd} @ \mathrm{rGO}$ nanocomposite, UV-Vis analyses was also performed (Fig. 1.4) The UV-Vis spectra of GO showed two absorption wavelenghts at around of 230 and $305 \mathrm{~nm}$ which were chiefly owing to $\pi \rightarrow \pi^{*}$ of $\mathrm{C}=\mathrm{C}$ and $\mathrm{n} \rightarrow \pi^{*}$ of $\mathrm{C}=\mathrm{O}$, respectively. In UV-Vis spectra of $\mathrm{rGO}$, the maxiumum peak at $230 \mathrm{~nm}$ was shifted $260 \mathrm{~nm}$ and the broad absorption peak at around $305 \mathrm{~nm}$ was vanished due to reduction $\mathrm{C}=\mathrm{O}$ functional group of $\mathrm{GO}$. In case of $\mathrm{Pd} @ \mathrm{rGO}$ nanocomposite, the attendance of Pd nanoparticles to rGO was caused to red shifting in absorption peak to $280 \mathrm{~nm}$.

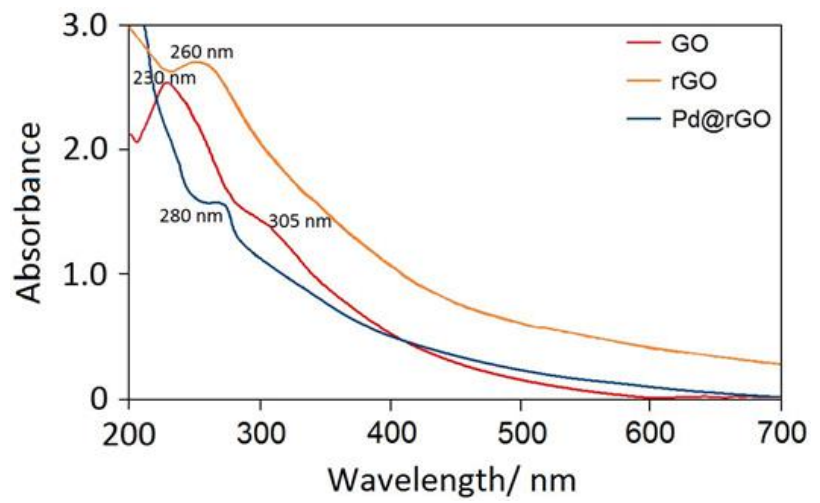

Fig. 1.4. UV-Vis absorption spectra of GO, rGO and $\mathrm{Pd} @ \mathrm{rGO}$ nanocomposite.

\section{References}

Kayan, D.B., Turunc, E. (2021). Bio-reduced GO/Pd nanocomposite as an efficient and green synthesized catalyst for hydrogen evolution reaction. International Journal of Energy Research, 1-11. https://doi.org/10.1002/er.6597. 